\title{
Adapting with Global Pandemic: Challenges and Recommendations for Playground Facilities
}

\author{
Sakina Ahmad ${ }^{1}$, Annisa Istighfari ${ }^{* *}$ \\ ${ }^{1,2}$ PT AEON Fantasy Indonesia \\ ${ }^{*}$ Corresponding author. Email: i_icha@aeonfantasy.co.id
}

\begin{abstract}
The ongoing Covid-19 pandemic has been affecting numerous business sectors globally. In Indonesia, millions of children stayed home while playgrounds were closed nationwide to prevent further spread of the virus. Past research explains the importance of playground visits for children's play and learning development, yet studies on ways to shift playground experiences and their benefits to online or other media are very rare. This paper will cover the advantages of playing in playgrounds through theoretical approach as well as offer several strategies to maintain this experience online during pandemic. Challenges, and different ways to solve them will also be discussed based on evidence of implementing those strategies by AEON Fantasy Indonesia, a Japan-based playground operator. Furthermore, not only for playground operators, recommendations featured in this study are also applicable for children, caregivers, and child development practitioners.
\end{abstract}

Keywords: playground, Covid-19, play, children development.

\section{INTRODUCTION}

In December 2019, an unknown pneumonia-like disease was reported in China's WHO Country Office. A month later, by January 2020, this outbreak was announced as a Public Health Emergency of International Concern by WHO which was later named as Covid-19 [1]. In Indonesia, this virus was predicted to have been spreading since January or February. However, the country's authorities only began reporting cases by March and found 96 cases within only two weeks [2]. By late May, the number of confirmed cases in Indonesia had floored up to over 20,000 cases and 1000 deaths, adding up to the 5 million cases and over 300,000 deaths globally [3].

This emergency forces people to stay inside and keep the distance from outdoor or crowded places which in turn, affected a lot of business. Playground business is one that was affected by the pandemic greatly [4]. By April 2020, all around Indonesia, 197 malls are closed, followed by the closing of all playgrounds under the operation of AEON Fantasy Indonesia [5], [6]. While it is usually located inside a shopping centre or outdoor crowd, it also has many youngsters and adults as customers- who are at risk of exposure to the virus [7], [8]. In addition, during this uncertainty, it is important for parents to maintain their children's health and safety by staying at home [9]. This series of events caused a huge plummet in the playground's visitors' number and continuity.

Not only impacting businesses, this situation also changes customer's behaviour. Almost any important activities are being done online. For example, school and learning activities for children are done via video calls or online assignment submission [10]. It is estimated that school and public facilities are closed. 1.6 billion children worldwide [11]. This is a huge challenge for children, caregivers and education service providers as children's learning patterns change dramatically by relying on online connections [12]. As interactions with the outside world are essential for children's lives, this sudden change started to lower children's overall wellbeing [13]. Even active classes like PE or extracurricular are also dismissed and shifted online which leads to a decrease in physical activities [14]. This might lead to minimal children's motoric and physical activity which may impact their physical or even mental health [15], [16].

For playground service providers, it is important to make sure children gain access to renewed playground experience and continue to receive positive impacts for their development. Ideally, playground business has a huge impact on children's education and physical development by the combination of play types available in the playground which help children to develop various motor skills [17]. However, as outdoor activities are 
being limited, parents and children must be creative to help children develop their skills with any means possible. To maintain business continuity and to keep serving its purpose to help parents and children's development, it is important for playground companies to understand strategies that should be implemented during this difficult time. This paper aims to review previous related studies to help answer the question: 1) how playground play experience helps develop various children's skills and abilities, and 2) what strategies are possible to implement to maintain the continuity of those experiences during global pandemic when most children's activities are done online.

\section{DISCUSSION}

\subsection{Playground Activities for Children's Development}

Not only in the classroom or through formal education, learning for children can happen anywhere. This part will specify various types of important activities happening in the playground environment, which are interactive play, abstract play, imaginative or pretend play, and physical activities. Vygotskian theory explains that by playing, children can maximize their development, or "a head taller by himself" [18]. Vygotsky's theory underlines the importance of interpersonal processes between more competent adults (parents or teachers) and children [19]. This process happens when competent adults provide a framework and scaffolding to allow the development of children's cognitive abilities. In a playground environment, the process of interactive play between parents and children can help children to maximize their potential by understanding various roles in child's play. The idea of interactive play is being implemented in various playgrounds in Indonesia, not only to maximize children development but also to build stronger parental bonds [20].

While Vygotskian theory emphasizes interpersonal or cultural processes, Jean Piaget's theory of cognitive development suggests that the play activity is literally cognitive development [21]. To illustrate, when provided with playground experience, with various challenges and games, children are constantly adjusting their mindsets or accommodating new information into knowledge [19]. Piaget explains that during their early years, children also learn to have flexible thinking, logical reasoning, even making concrete predictions or hypotheses [19]. In playgrounds context, playing with Play-dough, constructive toys, or Do-it Yourself kit can help children develop those abilities by finding various ways to play or accomplish a specific goal within the game. This explains that even abstract play, no matter how unstructured it is, can be impact for children.
Not only through interactions with competent adults or through challenging plays, children can also develop their skills by role playing with their peers. Dorion proposed that children can develop higher order thinking skills through this pretend play or role playing [22]. Meanwhile, Piaget mentioned that Children started to understand pretend play through object substitution around age 11-18 months and peaks at age 3-5 years, for example, playing with a Lego block and pretending as if it's a phone [23]. It is also common to find children engaging in a pretend play with specific scenarios like playing doctor and patient or any other role. Goldstein \& Lerner found that these types of dramatic pretend play help children grow empathy and emotional self-control through understanding assigned roles during play [24]. This proves that pretend play is an important activity as it nurtures both cognitive and social emotions abilities. In Indonesia, most playgrounds provide costumes, utensils, and create a place setting as real as possible to help children make scenarios for their pretend play activities [25].

Another distinct feature that distinguishes playground experience from other play media is the amount of physical activity and benefits. Despite that most playgrounds are massive in terms of size, one important factor of an effective physical activity is a diverse play facility for children [26], [27]. Reimers \& Knapp added that a combination of active play (ball, ride-on) and separated areas for each purpose are very attractive for children which increase their physical activities [27]. For instance, playgrounds that promote a healthy physical development have a specialized area for ride-on toys, role playing activities, hall for structured activities, and sitting area for particular types of toys. This point is also supported by a series of experimental studies by Broekhuizen, Scholten, \& de Vries which shows an increase in physical activity by accommodating lots of play varieties in a big playground area [28].

Regardless of which framework used to understand play activities, it is important to note that by playing, children can grow solid awareness of their senses and use it further to understand their environment [22]. This is a crucial step as it helps children to deal with social context and various personal or interpersonal problems during each developmental stage. Thus, by including various play activities for children, children can maximize their potential in various aspects of their lives [29]. These playful learning approaches can also foster children's abilities for school readiness and further academic success [30]. Moreover, modern playgrounds in Indonesia often hold seasonal activities, class, or structured play to give children more opportunities to train their skills [31]. These combinations between free or abstract play and structured activities in playgrounds can help promote healthy growth for children's development [17]. 


\subsection{Shifting Playground Experiences Online for Children}

Combining play and learning activities online, apparently, is not new. For instance, the term 'edutainment' coined to explain the hybrid between learning and entertainment, such as computer software, games, or multimedia [32]. This type of combination is widely used, especially in the current situation. There are plenty of works proving the effectiveness of edutainment on learning and child development [33], [34]. Report by PricewaterhouseCoopers from 2019 noted that around 6 million children in the world are active internet users, especially on YouTube, search engines, and Facebook [35]. With such big numbers, online play and learning activities should be easy to introduce to children as it is not strange or unfamiliar for them. Following paragraphs will provide recommendations for children, caregivers, and playground service providers to maintain positive impacts gained especially by playground visits.

One positive impact from playing together in playgrounds is stronger bonds and meaningful interactions between children and caregivers [36]. To support this, many playground service providers started selling Do-it Yourself kits and uploading tutorial videos for children and parents' activities [37], [38]. DIY activities might help parents and children to add more collaborative or interactive play activities into their routines. To increase collaborative activities between parents and children, some playgrounds arrange online contests or challenges with various rewards [39]. Rewards in games, like vouchers or toys, might reinforce them to do creative and interactive processes together to finish the challenge [40].

While children can be active when playing in playgrounds or outdoors, current physical distancing regulation might limit their regular physical activity [41]. Prolonged school closure might have negative effects on children's physical health as they are less active and have longer screen time [42]. To maintain optimal daily physical movement, some schools arrange online physical activities, such as dancing or doing light exercise together through an online conference app [43]. Parents can also choose from many choices as plenty of kids' sport schools or gyms conduct their classes online [44]. Using more screen time to stream physical activity classes might be beneficial, especially for children who do not have access to safe outdoor spaces [14].

Even though most play activities can easily be done together at home by parents and children, this situation might trigger parental stress due to sparing more time with children and less for parents [45], [46]. To deal with it, some playgrounds' social media provide quick tips, parenting articles, even teaming up with professionals to conduct workshops for parents to manage their stress or maintain effective communication with children [47].
Most papers and articles are focusing on maintaining good mental health and emotional bonds for caregivers and children during the pandemic by working together practicing mindfulness, acceptance, and self-compassion [46], [48]. It is also important for parents to have direct communication with children about current issues as it helps lower negative emotions [15]. More importantly, parents can use this period as an opportunity to strengthen bonds with children by applying the right parenting approach to meet children's psychological needs.

Uncertainties might also happen to the playground's staff, as their usual daily tasks are changing dramatically. Since their jobs are high in public interactions and have lower computer use than other jobs, they face higher job insecurity because working from home is a difficult choice [49]. The lack of face-to-face interaction between playground management and the staff also pushes for alternative ways of training and supervision. AEON Fantasy Indonesia started to depend on online connection for their workers by training staff through an online conference app and connecting staff and customers online through social media [38]. These strategies are expected to maintain productivity and create a collaborative working atmosphere at home, as going to work during the pandemic can be risky.

\section{CONCLUSION}

While affecting the playground industry and changing the way children play and interact with their caregivers, the current global pandemic also offers opportunities for playground businesses to come up with new ideas around providing play experiences. Ideally, these news ideas would encompass the main features of 'traditional' playgrounds such as interactive play, abstract play, imaginative or pretend play, and physical activities. During the pandemic, playground operators translated these features into selling DIY kits to try at home, creating online games, and posting video tutorials.

Moreover, transition from offline to online was not only done to the playground activities, but also to the staff who bear the most responsibility to communicate with customers. In order to maintain staff's health without sacrificing the quality of their work, playground operators conduct online staff training to maintain service quality even when working from home. Some playgrounds also support their staff productivity by having their staff making interactive videos to upload on the playground's social media so they can still interact with customers.

This study suggests several ways that playground managers can do to maintain productivity and customer satisfaction. However, there are few limitations on this study. First, this paper only touches on the broad topic of shifting playground experiences online without diminishing their advantages. Further research should be 
done to test the theories mentioned in this paper, especially in the context of a global pandemic, both from the point of view of the playground operators and the families who utilize their services. Moreover, experimental studies can also be beneficial as this paper focuses only on reviewing current phenomenon and available literature without conducting any statistical analysis.

\section{AUTHORS' CONTRIBUTIONS}

S.A.; Collected the data, Performed the analysis, Wrote the paper. A.I; Collected the data, Proofread and revised the paper.

\section{ACKNOWLEDGMENT}

This research is fully funded by PT AEON Fantasy Indonesia

\section{REFERENCES}

[1] WHO (World Health Organization). Rolling updates on Coronavirus Disease (COVID-19) [Internet]. WHO; 2020 [cited 2020 Jun 23]. Available from: https:/www.who.int/emergencies /diseases/novel-coronavirus-2019/events-as-theyhappen.

[2] The Jakarta Post. Stay home, President says [Internet]. Jakarta: The Jakarta Post; 2020 [cited 2020 May 27]. Available from: https://www.thejakartapost.com/news/2020/03/16/s tay-home-president-says.html.

[3] WorldOMeter. Coronavirus update (Live) [Internet]. WorldOMeter; 2020 [cited 2020 May 27]. Available from: https://www.worldometers. info/coronavirus/.

[4] AEON Fantasy Indonesia. Sales report March-June 2020. Jakarta: PT AEON Fantasy Indonesia; 2020. Unpublished.

[5] AEON Fantasy Indonesia. Operational activities during Covid-19 Pandemic. Jakarta: PT AEON Fantasy Indonesia; 2020. Unpublished.

[6] CNBC Indonesia. Waduh, ini 197 mal di Indonesia yang tutup akibat Corona! [Internet]. Jakarta: CNBC Indonesia; 2020 [cited 2020 May 27]. Available from:

https://www.cnbcindonesia.com/lifestyle/02004281 21158-33-154930/waduh-ini-197-mal-diindonesia-yang-tutup-akibat-corona

[7] BBC News. Coronavirus: Schoolchildren's risks of catching and spreading the disease [Internet]. BBC; 2020 [cited 2020 Jun 23]. Available from: https://www.bbc.com/news/health5200384

[8] WHO (World Health Organization). Coronavirus disease (COVID-19) advice for the public: Myth busters [Internet]. WHO; 2020 [cited 2020 Jun 23]. Available from: https://www.who.int/emergencies/ diseases/novel-coronavirus-2019/advice-forpublic/myth-busters.

[9] Cluver L, Lachman JM, Sherr L, Wessels I, Krug E, Rakotomalala S, et al. Parenting in a time of COVID-19. 2020 Apr 11 [cited 2020 Jun 23]. The Lancet [Internet]. 2020;395(10231):e64. Available from: https://pubmed.ncbi.nlm.nih.gov/32220657/ DOI: https://doi.org/10.1016/S0140-6736(20) 30736-4

[10] BBC News. How will coronavirus change the way we live? [Internet]. BBC News; 2020 [cited 2020 Jun 23]. Available from: https://www.bbc.com/ news/explainers/52356136.

[11] UNICEF. Keeping the world's children learning through COVID-19 [Internet]. UNICEF; 2020 [cited 2020 Jun 23]. Available from: https://www.unicef.org/coronavirus/keepingworlds-children-learning-through-covid-19.

[12] The Jakarta Post. Game changing Indonesia's education sector [Internet]. Jakarta: The Jakarta Post; 2020 [cited 2020 Jun 23]. Available from: https://www.thejakartapost.com/academia/2020/05/ 14/game-changing-indonesias-educationsector.html.

[13] Goldschmidt, K. The COVID-19 pandemic: Technology used to support the wellbeing of children. Journal of Pediatric Nursing [Internet]. 2020 April 16 [cited 2020 May 27]. DOI: DOI: https://doi.org/10.1016/j.pedn.2020.04.013.

[14] Rundle AG, Park Y, Herbstman, JB, Kinsey EW, Wang YC. COVID-19-related school closings and risk of weight gain among children. Obesity. 2020 Jun;28(6):1008-9. Available from: https://pubmed.ncbi.nlm.nih.gov/32227671/ DOI: 10.1002/oby. 22813 .

[15] Wang G, Zhang Y, Zhao J, Zhang J, Jiang F. Mitigate the effects of home confinement on children during the COVID-19 outbreak. The Lancet. 2020;395(10228): 945-94.

[16] Liu JJ, Bao Y, Huang X, Shi J, Lu L. Mental health considerations for children quarantined because of COVID 19. The Lancet Child \& Adolescent Health. 2020;4(5):347-49.

[17] Tortella P, Haga M, Loras H, Sigmundsson H, Fumagalli G. Motor skill development in Italian pre-school children induced by structured activities in a specific playground. PLoS One. 2016;11(7): $\mathrm{e} 0160244$

[18] Bodrova E, Germeroth C, Leong DJ. Play and selfregulation: lessons from Vygotsky. American Journal of Play. 2013;6(1):111-23. 
[19] King LA. The science of psychology: An appreciative view. New York: McGraw-Hill;2016.

[20] AEON Fantasy Indonesia. Kidzoona playground description [Internet]. AEON Fantasy Indonesia; n.d [cited 2020 Jun 2]. Retrieved from http://aeonfantasy.co.id/kidzooona.html.

[21] Ahmad S, Ch AH, Batool A, Sittar K, Malik M. Play and cognitive development: Formal operational perspective of Piaget's theory. Journal of Education and Practice. 2016;7(28):72-9.

[22] Cakici Y, Bayir E. Developing children's views of the nature of science through role play. International Journal of Science Education. 2012;34(7):1075-91

[23] Lillard AS. Why do the children (pretend) play? Trends in Cognitive Sciences. 2017;21(11):826-34.

[24] Goldstein TR, Lerner MD. Dramatic pretend play games uniquely improve emotional control in young children. Developmental Science. 2018;21(4):e12603.

[25] Now Jakarta. Let's Have Fun at These Top Jakarta's Indoor Playgrounds Top Indoor Playgrounds in Jakarta [Internet]. Now Jakarta; 2017 [cited 2020 May 27]. Available from https://nowjakarta.co.id/city-guide/explorejakarta /tons-of-fun-at-jakarta-s-indoor-playgrounds.

[26] Kaczynski AT, Potwarka LR, Saelens BE. Association of park size, distance, and features with physical activity in neighborhood parks. American Journal of Public Health. 2008; 98(8):1451-456.

[27] Reimers AK, Knapp G. Playground usage and physical activity levels of children based on playground spatial features. Journal of Public Health. 2017;25(6):661-69.

[28] Broekhuizen K, Scholten AM, De Vries SI. The value of (pre) school playgrounds for children's physical activity level: a systematic review. International Journal of Behavioral Nutrition and Physical Activity. 2014;11(1):1-28.

[29] Shim SY, Herwig, JE, Shelley M. Preschoolers' play behaviors with peers in classroom and playground settings. Journal of Research in Childhood Education. 2001;15(2):149-63.

[30] O'Sullivan L, Ring E. Play as learning: implications for educators and parents from findings of a national evaluation of school readiness in Ireland. International Journal of Play. 2018;7(3):266-89.

[31] What's New Jakarta. 16 best playgrounds for kids in Jakarta (indoor \& outdoor) [Internet]. 2020 [cited 2020 May 27]. Available from: https://whatsnewindonesia.com/jakarta/16-bestplaygrounds-for-kids-in-jakarta-indoor-outdoor/.

[32] Depickere A, Fung C, Rapeepisarn K, Wong KW. Similarities and differences between" learn through play" and "edutainment". Proceedings of the 3rd Australasian Conference on Interactive Entertainment [Internet]. 2004 [Cited 2020 Jun 23];28-2. Available from: https://researchrepository.murdoch.edu.au/id/eprint 1993/.

[33] Dandashi A, Karkar AG, Saad S, Barhoumi Z, AlJaam J, El Saddik A. Enhancing the cognitive and learning skills of children with intellectual disability through physical activity and edutainment games. International Journal of Distributed Sensor Networks. 2015;11(6):1-11.

[34] Feenstra F, Muzellec L, de Faultrier B, Boulay J. Edutainment experiences for children in retail stores, from a child's perspective. Journal of Retailing and Consumer Services. 2015;26:47-56.

[35] PricewaterhouseCoopers. Kids Digital Media Report 2019 [Internet]. Pricewaterhouse Coopers; 2019 [cited 2020 May 27]. Available from: https://gertkoot.files.wordpress.com/2019/06/kidsdigital-media-report-2019-.pdf.

[36] Milteer RM, Ginsburg KR, Mulligan DA. The importance of play in promoting healthy child development and maintaining strong parent-child bond: Focus on children in poverty. Pediatrics. 2012;129(1):e204-e13.

[37] Fanpekka Indonesia. Hello, Moms! Selama \#dirumahaja, Moms pasti ingin selalu belajar dan bermain bersama si kecil [Internet]. 2020 May 1 [cited 2020 May 27]. Available from: https://www.instagram.com/p/B_o235h_qn/

[38] Kidzoona Indonesia. Membuat Hiasan Dinding bersama Kakak Caswa [Internet]. 2020 Apr 25 [cited $2020 \mathrm{Mau}$ 27]. Available from: https://www.instagram.com/tv/B_Zsv_olgg/.

[39] Kidzoona Indonesia. SURPRISE! kidzoona dan Fanpekka kembali lagi nih, dengan kegiatan seru selama \#dirumahaja [Internet]. 2020 Apr 27 [cited 2020 May 27]. Available from https://www.instagram.com/p/B_ev25aly7/.

[40] Byron K, Khazanchi S. Rewards and creative performance: a meta-analytic test of theoretically derived hypotheses. Psychological Bulletin. 2012;138(4):809-30.

[41] Guan H, Okely AD, Aguilar-Farias N, del Pozo Cruz B, Draper CE, El Hamdouchi A, et al. Promoting healthy movement behaviours among children during the COVID-19 pandemic. The Lancet Child \& Adolescent Health. 2020:4(6):41618.

[42] Brazendale K, Beets MW, Weaver RG, Pate RR, Turner-McGrievy GM, Kaczynski AT, et al. Understanding differences between summer vs. school obesogenic behaviors of children: the structured days hypothesis. International Journal of 
Behavioral Nutrition and Physical Activity. 2017;14(1):1-4.

[43] Kompas. Belajar di rumah, begini cara siswa olahraga secara online [Internet]. 2020 [cited 2020 Jun 23]. Available from: https://www.kompas.com/edu/read/2020/ 4/07/150402271/belajar-di-rumah-begini-carasiswa-olahraga-secara-online?page $=$ al.

[44] Parent Story. Roller Skool - Fun off-skate online 2 session [Internet]. Parentstory; n.d. Available from https://www.parentstory.com/course/4813.

[45] Michigan News. Parents are having more conflict with children since pandemic [Internet]. Michigan News; 2020. Available from: https://news.umich.edu/coronavirus-causingconflict-between-parents-children/.

[46] UNICEF. Coronavirus (COVID-19) parenting tips [Internet]. UNICEF; 2020 [cited 2020 Jun 23]. Available from: https://www.unicef.org/ coronavirus/covid-19-parenting-tips.

[47] Bumi Playscape. Karantina membuat anak sulit untuk memiliki waktu bermain dengan teman sebayanya [Insternet]. 2020 Jun 3 [cited 2020 Jun 3]. Available from: https://www.instagram.com/p/ CASmIvgWJw.

[48] Coyne LW, Gould ER, Grimaldi M, Wilson KG, Baffuto G, Biglan A. First things first: Parent psychological flexibility and self-compassion during COVID-19. OSF Preprints [Internet]. 2020 [cited 2020 Jun 23]. Available from: osf/io/pyge2.

[49] Baker MG. Characterizing occupations that cannot work from home: a means to identify susceptible worker groups during the COVID-19 pandemic. medRxiv. 2020. 